\title{
UNIVERSITYOF
}

FORWARD

THINKING

WESTMINSTER用

WestminsterResearch

http://www.westminster.ac.uk/westminsterresearch

Conceptualising a distributed, multi-scalar global public sphere through activist communication practices in the World Social

Forum

Stephansen, $\mathbf{H}$.

This is a copy of the accepted author manuscript of the following article: Stephansen, $\mathrm{H}$. (2019) Conceptualising a distributed, multi-scalar global public sphere through activist communication practices in the World Social Forum, Global Media and Communicatio,. Advanced online publication. The final definitive version is available from the publisher Sage at:

https://doi.org/10.1177/1742766519872777

(C) The Author(s) 2019

The WestminsterResearch online digital archive at the University of Westminster aims to make the research output of the University available to a wider audience. Copyright and Moral Rights remain with the authors and/or copyright owners.

Whilst further distribution of specific materials from within this archive is forbidden, you may freely distribute the URL of WestminsterResearch: ((http://westminsterresearch.wmin.ac.uk/)).

In case of abuse or copyright appearing without permission e-mail repository@westminster.ac.uk 


\section{Conceptualising a distributed, multi-scalar global public sphere through activist communication practices in the World Social Forum}

Hilde C. Stephansen, University of Westminster

\section{Abstract}

The term 'global public sphere' has often been used to describe global-scale spaces of discourse, yet there are several difficulties involved in 'scaling up' the public sphere concept. Drawing on ethnographic research on media activism in the World Social Forum, this article shows how 'global publics' are created by media activists through a broad range of communication practices, including efforts to create 'placebased' publics that connect to global struggles and the use of videoconference technology to create a sense of global connectedness among marginalised communities. The article analyses the complex politics of scale involved in these communication practices, critically interrogating the categories of 'global' and 'local'. It proposes a dynamic understanding of the 'global public sphere' as constituted through the interlinking of diverse, multiply scaled - yet globally oriented communication practices, and emphasises the importance of efforts to create and strengthen collective, autonomous communication spaces at multiple scales.

\section{Introduction}

As flows and patterns of communication increasingly crisscross scales and localities, it decreasingly makes sense to talk about the public sphere as a bounded communication space corresponding to the territory of the nation state. Multiple examples of transnational and translocal communication networks, such as those involving protest movements, complicate such an understanding. Still, the notion of a global public sphere is difficult to conceive both in theory and practice. As Fraser (2007) has argued, the concept of the public sphere as traditionally understood is distinctly Westphalian - it presupposes a modern state structure, a territorially bounded political community, a national economy, national media, and linguistic and cultural homogeneity. It is therefore difficult to 'scale up' from its national origins (ŸlaAnttila, 2005) - at least if by 'public sphere' we mean a unified communication space at the global scale forming the counterpart to a global state authority.

Add to this the fundamental transformations in media infrastructures and -practices we have seen over the last decade with the rise of corporate social media platforms. While the notion of a public sphere is suggestive of a relatively stable spatial configuration (a public communication space supported by mass media) the communication patterns engendered by social media are much more shifting and dynamic - and far from self-evidently public (Poell and Van Dijck 2016). Social media tend to facilitate more individualised, affective and personalised forms of 
communication that emphasise visibility and immediacy, which is far from conducive to the kind of reasoned debate and collective opinion-formation implied by public sphere theory (Bennett \& Segerberg 2013, Milan 2015a, Barassi 2015a, Kaun 2015). Moreover, the algorithmic determination of visibility (Leistert 2015, Milan 2015b) combined with the 'filter bubble' effect of social media, makes the publicness of online communication questionable. It seems, then, that - with or without the 'global' prefix - the concept of the public sphere as a unified, openly accessible communication space is increasingly difficult to maintain.

The aim of this article is to contribute to contemporary conceptualisations of the global public sphere, drawing on empirical research on the practices of media activists involved in the World Social Forum (WSF) - a global gathering of civil society actors that has been referred to as a global public sphere (e.g. Smith 2004). In what follows, I begin by outlining scholarship that has conceptualised publics as distributed, networked and emergent, and bring this together with recent conceptualisations of 'media as practice' to propose an understanding of publics as constituted through communication practices. I then explore examples of activist communication practices in the WSF process that might be understood as contributing to the creation of plural, multi-scalar 'global publics' - and suggest that these practices signal a model of the 'global public sphere' that is decentred, distributed and made up of multiple overlapping publics at different scales.

\section{Conceptualising the global public sphere}

There is a growing literature that contributes to conceptualising the 'global public sphere'. Focusing on the difficulties involved in 'scaling up' the public sphere concept from its Westphalian origins, Fraser (2007) has framed the challenge in terms of constructing a transnational public sphere. As a critical theorist, Fraser's concern is with how the legitimacy and efficacy of public opinion can be assured if the public sphere no longer corresponds to the territory and authority of the nation state. At stake in contemporary public sphere debates, however, is not just the question of how to conceptualise the shift from national to transnational scales of deliberation, but also the relationship between the 'local' and the 'global'. The internet has given rise to complex communication flows that crisscross scales and localities, enabling processes that fundamentally challenge conventional understandings of scale as nested within spatial hierarchies (Sassen 2006). As Sassen (2006) has argued, the decentralised simultaneous access afforded by the internet can help local actors have a sense of participation in globally distributed struggles. New communication technologies can contribute to the formation of 'cross-border publics spheres' that bypass central authority, and, in this way, 'distributed immobilities can actually come to constitute global publics' (ibid.: 366). Although the actors that form part of such publics may remain focused on their localities, they do so with the knowledge and invocation that multiple other 'local' actors around the world are involved in similar struggles (Sassen 2006). This combination of self-reflexivity and multiplication helps 
'constitute a global condition out of these localized practices and rhetorics' (ibid.: 373). From such a perspective, the notion of a global public sphere need not refer to a communication space 'above' the national and the local. Highlighting the global dimension of many localised practices, Sassen's work points towards a conceptualisation of the global public sphere as decentred, distributed and networked - comprised of multiply scaled, yet interlinked, communicative spheres.

The spatial assumptions that underpin traditional public sphere conceptions have been further challenged by more recent scholarship, which has explored the implications of the rise of digital and networked media. Within social movement studies, scholars have highlighted a shift towards more personalised and individualised forms of political engagement. For Bennett and Segerberg (2013), this involves a shift from 'collective action', based on strong collective identities and organisational co-ordination of action, towards 'connective action' driven by selfmotivated sharing of personalised ideas and resources via social media platforms, with little formal co-ordination. Milan's (2015a, 2015b) notion of 'cloud protesting' highlights the emergence of new, individualised forms of mobilisation, enabled by (and modelled on) social media, in which subjective experience and visibility are central. In these accounts, contemporary forms of collective action assume a networked, dispersed and often fleeting character. The articulations enabled by social media tend to be fluid and ephemeral - raising questions about their capacity to generate communication spaces that can support more sustained forms of deliberation and collective action (cf. Barassi 2015a; Juris 2012; Kaun 2015; Milan 2015a).

The increasingly personalised nature of contemporary communication processes has also been highlighted by media scholars. Schmidt (2014) points to the emergence of 'personal publics', constituted by the personal networks created by social media users, which play an increasingly central role as conduits for the circulation of information. The concept of 'networked publics' points to the way networked technologies "reorganize how information flows and how people interact with information and each other" (boyd 2011: 41; see also Varnelis 2008; Papacharissi 2012). Characterised by a blurring of public and private communication, networked publics lead to 'context collapse': the bringing together of previously separate spheres of social life within the same communicative sphere (boyd 2011). The notion of context collapse has mostly been used to refer to social contexts, but can equally be applied to scalar contexts: social networking sites bring geographically distant and close actors into the same networked sphere, leading to an interweaving of previously distinct and hierarchically 'nested' scalar dimensions.

The consequences of these and related dynamics for public sphere theory have been explored by Volkmer (2014), who conceptualises the global public sphere as constituted through the communication of content through multi-level, multi-platform, personal network structures linking individuals across the globe. For Volkmer, the 
local, national and global are no longer distinct spheres, but merge within subjective 'micro-networks'. The global public sphere does not exist 'out there' but rather "right here' in the way content trajectories are chosen, intersect and relate within the site of a subjective networked 'universe', synchronized across devices and always available" (2014: 3-4). Volkmer highlights the vertical 'anchoring' or 'contraction' of globalized network formations as the lifeworld becomes the site connecting transnational discursive flows and subjective experience. In advanced globalization, the sphere of deliberation is thus situated not in the space between the nation-state and the 'people' but rather in a new space "between globalized public trajectories and local action" (2014: 114). Volkmer uses the term 'reflective inbetweenness' to refer to the continuous self-confrontation of subjects as they encounter situations of public interdependence. This constant movement not only between the global and the local but "between the 'world' and 'me'" (115) constitutes a reflective form of deliberation that opens up discursive space connecting transnationally dispersed interlocutors. Volkmer suggests a conceptual move from 'the public sphere' to 'public horizons', which emerge through the engagement of the 'civic self' with multiple, subjectively constructed discursive networks, and enable new forms of globally oriented 'discursive consciousness'.

These accounts complicate conventional understandings of the public sphere as a spatial container for public deliberation, and emphasise instead the distributed, networked and fluid character of contemporary public communication. As they have no location, networked publics are "empirically discernible only as specific practices of communication, through temporary sites of negotiation or through fleeting networks of actors" (Lünenborg and Raetzsch 2017: 20, emphasis in original). As Poell and Van Dijck (2016: 232) argue, rather than look for a public sphere we should therefore examine trajectories of publicness, "which entails tracing how public spaces are constructed, that is, opened up for public expression and contestation, as well as how they are closed down". In other words, we need to pay attention to the ways in which publics (in the plural) emerge in specific contexts.

Two key features of contemporary publics stand out from the accounts outlined above: their temporary and dispersed nature, and the increasingly personalised and subjective character of public communication. This has important implications for democracy as it raises questions about the possibility of creating more durable, collective communication spaces. As Fraser's (1990) concept of 'subaltern counterpublics' reminds us, such communication spaces have traditionally performed a vital democratic function by enabling marginalised groups to develop their own discourses and identities, away from the pressures of mainstream publics. However, the picture painted by contemporary theorisations is one of publics as made up of individual 'nodes' situated within constantly shifting network formations, with no clear separation between counter- and mainstream public spheres. In this scenario, prospects for more sustained, collective processes of identity formation and knowledge production among subordinate groups seem limited. 
While the dynamics discussed above do indeed pose challenges in this respect, public sphere debates risk missing important features of contemporary processes of public formation due to a tendency to take media platforms and media content as a starting point. In most of the accounts outlined above, publics are understood as constituted primarily through the circulation of discourse - in other words, it is in the creation, sharing and consumption of media content that publics emerge. While the discursive dimension of publics is undoubtedly significant (cf. Warner 2002), it is important to also consider their material and social foundations. Publics emerge not just through the circulation of discourse but depend on material practices and (social and technical) infrastructures for their existence (cf. Jackson 2011; Kelty 2010; Marres 2012). As elaborated below, publics can be conceptualised as constituted through communication practices.

\section{Media as practice}

Prompted by a 'practice turn' within the social sciences (see e.g. Schatzki et al 2001; Reckwitz 2002; Shove et al 2012), an understanding of media as practice has gained prominence among media researchers over the last decade. This engagement with practice is particularly associated with the work of Nick Couldry (2004, 2012 - see also Bräuchler \& Postill, 2010), who has proposed a practice framework as an alternative to the two dominant traditions in media research: political economy and textual analysis. Drawing on conceptualisations of practice in social theory, which understand practice as the site where social order is reproduced, Couldry suggests that a practice approach

starts not with media texts or media institutions but from media-related practice in all its looseness and openness. It asks quite simply: what are people (individuals, groups, institutions) doing in relation to media across a whole range of situations and contexts? How is people's media-related practice related, in turn, to their wider agency? (Couldry, 2012:37).

This understanding of media as practice has been widely adopted among scholars of activist- and social movement media, as a means to develop non-media-centric analyses of activists' engagement with media (see e.g. Mattoni 2012, Mattoni \& Treré 2014, Barassi 2015b, Stephansen 2016). Highlighting the wide range of media practices that activists engage in, such work has sought to challenge technological determinism and 'one-medium bias' (Treré 2012; Mattoni and Treré 2014), to provide more nuanced analyses of the movement-media nexus that take into account the social and material contexts in which activists operate.

Because it focuses attention on the social processes that are enacted through media-related practices, the media practice approach can be used to develop an understanding of publics as constituted through communication practices 
(Stephansen 2016). Lünenborg and Raetzsch (2017) use the concept of media practice to "capture and analyse quotidian routines of communication in their relevance for the emergence of publics" (23). Combining insights from practice theory with Butler's (1990) concept of performativity, they develop the concept of 'performative publics' to propose an understanding of publics as brought into being through practices (rather than as pre-existing entities). Lünenborg and Raetzsch thus argue that media practice can be used as an analytic model to "investigate the new dynamics of publics emerging at the intersections of individual and collective articulations, between localised presence and translocal circulation and between emergent and resistant social orders" (2017: 28). An understanding of media as practice, in other words, appears highly suitable for exploring empirically the distributed, networked and multi-scalar character of contemporary public formations.

The media practice approach also provides an important corrective to disembodied understandings of publics as constituted through discourse, as it draws attention to the social and material foundations of publics. As Mattoni (2012: 159) has shown, 'activist media practices' include interactions within media subjects (such as journalists and other activists) as well as media objects (i.e. technologies). Similarly, scholarship on alternative and citizens' media has emphasised the social relationships, organisational forms and prefigurative politics that underpin such media (Atton 2002, Downing 2001, Rodríguez 2001). I therefore use 'communication practices' here as a comprehensive term to account for face-to-face and interpersonal communication as well practices involving media technologies. A practice approach enables us to see the more 'subterranean' aspects of activist communication practices, beyond what is visible online, and consider how such practices may contribute to the formation - and linking - of publics at different scales. A practice approach, as I will show in what follows, can also bring into view practices aimed at creating collective communication spaces - practices that risk being rendered invisible if we take the self-motivated sharing of personalised content across digital, networked media platforms as the only entry point for enquiry.

This concern with communication practices necessarily goes hand in hand with a focus on imaginaries. According to widely shared definitions, 'practices' are embodied forms of human activity that involve shared understandings, interpretations, emotions and motivations (Schatzki 2001; Reckwitz 2002). As outlined above, subjective awareness of a global condition figure centrally in recent conceptualisations of global publics (Sassen 2006; Volkmer 2014), and research has shown that imaginaries of networked technologies figure centrally in activists' organisational practices and engagement with digital media (Fotopoulou 2017; Juris 2008). As I show in what follows, media activists involved in the WSF operate with distinct imaginaries of the global, which inform and shape their communication practices. I argue that even when such practices are largely 'local' or place-based in orientation, they are still informed by a sense of global connectedness - and that 
such affective investment in the idea of globality can be an important factor in the constitution of global publics.

The analysis presented below draws on a larger ethnographic study of media activism in the WSF, conducted between 2008 and 2018. During this period, I attended numerous social forums (including the WSF 2009 in Bélem, Brazil, the WSF 2011 in Dakar, Senegal, the WSF 2013 in Tunis and the WSF 2018 in Salvador, Brazil - as well as several local, regional and thematic social forums), conducted 100 in-depth interviews, and accompanied online organising processes between forum events. The data used here are drawn primarily from participant observation and interviews with media activists conducted around the WSF 2009 in Bélem (where I spent five months from November 2008 to March 2009) and at a small social forum held in the southern Brazilian city of Pelotas in February 2010. Interviewees were recruited through a snowball sampling technique, and asked questions about their media practices, motivations, and engagement with the WSF. Data analysis was conducted using NVivo to identify key themes.

\section{Activist communication practices in the World Social Forum}

First held in 2001 in Porto Alegre, Brazil, the World Social Forum (WSF) has since its inception provided a space for media activists from around the world to exchange knowledge and experience, and develop a sense of solidarity and common purpose. Over the years this has facilitated the creation of transnational networks of media activists, who operate in multiple national and subnational contexts but see themselves as globally connected. As I have shown elsewhere (Stephansen 2016) the impetus for these networks was initially provided by the need to share alternative media content (at a time when web 2.0 technologies were in their infancy). In preparation for the first WSF, organisers created a copyleft-based web platform, enabling media activists to pool resources and share content. However, the WSF also provided an occasion for media activists from around the world to get to know one another and work together. Alternative media centres, providing space and equipment for activists to produce collaborative coverage of social forum events, have been organised at several subsequent WSF events. Activists sought to engage in a prefigurative politics, putting into practice a model of communication based on openness, collaboration and sharing - referred to as 'shared communication' - that they would like to see implemented at a wider scale. The spaces of sociality created by such media centres also provided the opportunity for participants to discuss media and communication as political issues in their own right, creating a growing sense of collective identity as a movement focused on media and communication (Stephansen 2017).

The most obvious way in which such media activism can contribute to the formation of a global public sphere is perhaps through the circulation of alternative media content through transnational movement networks. A media practice approach, 
however, can bring into a view a much broader range of activist communication practices, beyond those directly concerned with the production and circulation of content. Among media activists in the WSF, these include organisational practices involving collaborative and participatory production processes; capacity-building practices aimed at empowering grassroots activists to produce their own media; and network-building practices concerned with creating a sense of solidarity and common purpose among activists (Stephansen 2016).

A focus on practices also reveals the multi-scalar character of these activists' communication networks. Their efforts to build and strengthen networks among alternative media producers around the world clearly entail a global ambition: an ongoing concern has been to make the WSF a global process rather than just a series of events. However, this global ambition has been accompanied by a strong commitment to strengthening local and regional communication networks among grassroots movements in the places where the WSF is held. In particular, Brazilian activists involved in Ciranda, a network of media activists that emerged out of the WSF, have emphasised the importance of capacity-building to enable such movements to communicate on their own terms. As one of the co-ordinators of Ciranda explained:

You can arrive at the Forum, do [...] various documentaries, or various reports, because you get there, and you know how to do it, and you have the equipment $[\ldots]$ and you are a friend of the movements. In this case, you will do communication for the social movements. Another thing is these movements doing their own communication. (interview with author, 2009, translated from Portuguese)

One example of how this commitment manifested itself in practice was the WSF 2009 in Belém, Brazil, where Ciranda worked with a local NGO to build capacity and strengthen links among media activists in and around the city. In the next section, I focus on how local media activists connected to this NGO sought to make use of the WSF to strengthen communication networks among movements in the Amazon region (see Stephansen 2013a). While they were motivated and encouraged by the possibility of connecting with global publics through online platforms, their main concern was to create and strengthen what we might think of as a place-based public: a communicative sphere that is both grounded in, and contributes to the construction of meaning about, a particular geographical territory.

Place-based publics

CEPEPO, the organisation at the centre of this work, was an NGO that worked with audiovisual media as a tool for popular education, using film and photography as pedagogical tools to help marginalised communities reflect on their struggles and realities. CEPEPO worked to raise awareness among movements in Belém and the 
wider Amazon region about the strategic importance of communication, to empower activists to appropriate communications technologies for their own purposes. The organisation's work was strongly informed by activists' experience of place-based struggles and their commitment to their local community and the wider Amazon region. CEPEPO activists saw the WSF as an opportunity to 'give voice' to movements in the Amazon, and a sense of being able to connect to the global by making their work available online was a great source of confidence and motivation. During the WSF, CEPEPO activists produced several short video documentaries covering aspects of the event, and made a conscious decision to focus primarily on issues relating to the Amazon. They saw the WSF as opening up a space not normally available to movements in the region and wanted to take advantage of this.

On one level, this might be read as an attempt by 'local' actors, concerned primarily with their own issues, to appeal to a global public for support. However, a closer look reveals a more complex picture, because disseminating knowledge about the Amazon 'upwards' to a global public was not necessarily CEPEPO's primary concern. Equally important was making media content available to a regional public. The rationale behind this was that while information about the Amazon was easily available in other parts of the world, it did not necessarily reach people in the region, because of poorly developed communication infrastructures and movements' lack of access to mainstream media. Facilitating the circulation of information about the work of social movements within the Amazon was therefore a priority. As CEPEPO's director explained:

First, I think [our audience is] Belém and the Amazon [...]. It's a very big complaint among the social movements that we don't see ourselves, we don't communicate what we are doing, neither to ourselves nor to civil society [...]. I think first here, because sometimes it is much easier to have information about the Amazon in [your] country, in São Paulo... but we don't have this information here for society to know. (interview with author, 2009, translated from Portuguese)

Conscious of how movements and communities in the Amazon tend to be excluded from global communication networks, CEPEPO activists sought not simply to enable movements in the Amazon to get their message across to a global public. They also sought to create a space in which these movements could elaborate what that message might be. We can conceptualise this as an attempt to create a place-based public in the Amazon, through the circulation of media content in regional networks and through a capacity-building approach that sought to involve regional actors in the production of such media content. A key aim was to create conditions for production of knowledge in, about, and for the Amazon, starting from the realities of people living in the region. Such a project also necessarily involved working to create a place-based sense of identity. The complaint that "we don't see ourselves" is telling in this respect: activists' concern to strengthen communication networks in the 
Amazon was not just about rectifying a lack of factual information; it was also about constructing shared understandings of the Amazon as a place. Far from insular, however, the place-based public that activists sought to construct provided a basis for movements in the Amazon to engage with wider publics. Fraser's (1990: 68) understanding of subaltern counterpublics, as "spaces of withdrawal and regroupment" and as bases for engaging with wider publics, is worth recalling here. Before 'going global', movements in the Amazon first needed to create their own place-based public to facilitate autonomous processes of knowledge production and identity formation. The possibility of connecting to global communication networks provided the impetus for this project of public-making.

\section{Extending the WSF}

Another example of how the 'global' and the 'local' intersect in complex ways in the WSF is provided by a set of practices concerned with 'extending' social forums through the use of Skype videoconferencing technology (see Stephansen 2013b). The idea of an 'extended' social forum was first introduced at the WSF 2009, where activists involved in the forum's Communication Commission organised a series of live audio-visual connections between forum participants and activists in other parts of the world. The basic idea was to enable people who were not able to physically attend the forum to participate at a distance. Conceptualised as part of a decentralised and extended WSF, several events including meetings, rallies and workshops were held around the world, connecting in real time with Belém. Such 'extended' activities have since been organised at several subsequent social forums.

From the perspective of a liberal model of inclusion, these efforts to extend the WSF might be seen as a way to make the WSF truly open and inclusive. Skype videoconferencing provides a cheap and (usually) easy way to include activists who are unable to travel within the global public gathered at the WSF, approximating the kind of face-to-face interaction previously only possible among actors who are physically co-present. In this way, activists who cannot physically attend are able to participate in debates and share knowledge and experience with those present at the forum. However, the significance of these communication practices cannot be fully grasped within a liberal framework of inclusion. The encounters made possible by Skype calls are not simply a means to include, through rational debate and exchange of ideas, perspectives previously excluded from the WSF. Such encounters are significant in their own right, due to their strong affective dimension. This comes across clearly in one organiser's distinction between 'cold' and 'warm' communication:

Cold intercommunication is through email so it's not instant [...], your counterpart is an abstract partner. This is a place for planning, for making arguments, presenting papers, presenting ideas, structures etcetera, but it's 
not the place for emotion. Emotion [...] comes from seeing people and hearing them and the voice, the smile. (interview with author, 2009)

The emphasis placed here on the multi-sensory experience facilitated by live audiovisual connections suggests that what is most significant about such communication practices is that they make the experience of the encounter available to activists who cannot physically attend. Arguably, the visceral experience of being physically copresent with people from all over the world who share the same basic political vision is one of the most powerful features of social forums (Osterweil, 2004). As the same organiser explained,

I think the experience of encounter is a big component of the attractiveness of social forums. This can be a very basic feeling [...] at individual level then you can get to a collective feeling like your organisation encountering together $[\ldots]$ That's the main output of the Forum because then people develop the feeling of understanding, a feeling of solidarity [...] It's not just sharing abstract ideas. (interview with author, 2009)

In this sense, making the 'experience of encounter' available to those who cannot be physically present can be understood as an attempt to create a sense of belonging to a global process. The use of videoconference technology to connect activists in different places has an important symbolic function, in the sense that it generates a feeling of being connected to the global. Extending the WSF through videoconferencing technology is not only about extending the forum 'territory' to include more actors and ideas; it is also about extending the idea of the WSF. As one member of the WSF Communication Commission suggested, "even just the idea of being able to connect, for a group to [connect with] another group at a distance, already, it brings a lot of enthusiasm". In other words, it is perhaps the ability to connect that is most significant in terms of generating a sense of participation in a global WSF public.

This sense of global connectedness can be a source of strength and motivation for activists whose work is otherwise primarily place-based in orientation. An example that illustrates this point well is the Expanded Social Forum of the Peripheries, a small social forum held in 2010 in Dunas, a poor urban neighbourhood on the periphery of the city of Pelotas, just three hours by bus from the WSF's birthplace in Porto Alegre [reference]. Home to a predominantly Afro-Brazilian population of around 30,000 people, Dunas suffers from a lack of basic infrastructure, low education levels, problems with drugs and alcohol, and stigmatisation in mainstream public opinion as a place of crime and violence. The Expanded Social Forum of the Peripheries was held in a local community centre and organisers adopted the concept of an extended social forum for their own purposes. The forum was streamed live online, and many of the seminars incorporated Skype connections with activists in other parts of the world. Organisers emphasised the importance of 
constructing communication networks beyond their immediate locality, and saw videoconferencing as a means to facilitate knowledge exchange. However, their networking strategies were closely bound up with a place-making project that aimed to instill a sense of pride and commitment to their community among local residents. Motivated by a strong commitment to Dunas as a place, the organisers' key objectives were to empower the local community. Their work to construct transnational communication networks was motivated by a concern to create a sense of globality, which in turn could be mobilised to give momentum to a placebased project of social transformation. As one organiser explained:

If the community realises that it is [...] being seen, it is being looked at, that it is being visited by outsiders, the community has a tendency to like this [place] more, to like and then care for and participate. (interview with author, 2010, translated from Portuguese)

Organisers' efforts to create a sense of Dunas as a place that was of interest to 'outsiders' and connected to other places was about staking a claim for Dunas to be situated in the world, as part of the global, rather than relegated to the status of local and marginal. This involved constructing a sense of the global as constituted through translocal connections, achieved through innovative use of new communication technologies, and using this as a resource for empowering local struggles. As with the previous examples, a focus on communication practices, and the imaginaries that accompany such practices, bring into view the multi-scalar character of activists' communication networks.

\section{Discussion}

The examples discussed here pre-date the emergence of the 'movements of the squares' in 2011 and subsequent explosion in academic literature on protest movements and social media, but this does not lessen their relevance. Focusing on the practices and imaginaries of communities who have very limited internet access and whose main mode of communication is not social media, they offer a view of globality and networked politics from the perspective of actors who are not the usual protagonists of contemporary narratives about global connectedness. The WSF has been dominated by a highly mobile cosmopolitan elite of scholar-activists (Pleyers 2008; Conway 2012), who because of their mobility and transnational connections get constructed as 'global' actors, while place-based movements (of indigenous peoples, rural populations, and the urban poor) tend to be constructed as 'local' and further marginalised. However, the local-global language that is commonly used to talk about transnational movement networks "fails to problematize what gets labeled local or global and obscures the many other scales of action, their interdependence, and mutual constitution" (Conway, 2008: 218). It is important to note that, though not identical, hierarchies of scale overlap in important ways with colonial hierarchies of race: "white or light-skinned Europeans and Euro-descendants are 
overrepresented among the intellectual elites that are positioned as 'global', while indigenous peoples, Afrodescendants and other racialised groups figure more prominently among those designated as 'local'" (Stephansen 2013a: 106). Placebased yet globally oriented, the practices and imaginaries of media activists involved in the WSF challenge any neat separation between the 'local' and 'global' as well as the hierarchy between them. For media activists in Belém, the arrival of the WSF and the possibility of connecting to global networks gave impetus to a project concerned with the creation of a place-based public in the Amazon region. Far from insular, this public was conceptualised by activists as providing a necessary foundation for engaging wider publics at different scales. In the case of practices concerned with 'extending' the WSF, we saw how videoconferencing technology has been used to generate affective investment in the idea of global connectedness. The example of the Expanded Social Forum of the Peripheries showed how this sense of globality can be a source of motivation and confidence for place-based grassroots activists.

The place-based yet global politics practiced by media activists involved in the WSF challenges conventional understandings of scale. It resonates with the literature on networked and global publics discussed above insofar as it emphasises the complex ways in which the local and global can intersect in contemporary communication practices. However, the practices discussed here depart from the currently dominant understanding of contemporary publics as fleeting and driven by individualised modes of communication. They are very much oriented towards the construction of durable, collective communication spaces that can support autonomous processes of knowledge production and identity formation among communities at the peripheries of the global network society. The communication practices of activists in Belém and Dunas involve a clear claim to globality - to being part of the global - but it is one that is grounded in a commitment to place and community. While contemporary theorisations see publics as made up of individual nodes situated within shifting, dispersed network formations, the practices discussed here draw attention to the continued importance that many media activists place on constructing collective public spaces at different scales. This has normative implications for how we might conceptualise the global public sphere. Recalling the democratic function of 'subaltern counterpublics' (Fraser 1990), the kind of global public sphere that would best serve place-based communities is neither a unified communication space at the global scale nor a networked public driven by the personalised (though globally conscious) communication practices of individuals. It is perhaps better conceptualised as an always-emergent formation, responsive to shifting contexts and needs, made up of multiple, overlapping public spheres at different scales, connected through a sense of globality that gives impetus to projects at local and other scales. 
It might be argued that much has changed since the fieldwork reported here was conducted: surely the rise of corporate social media platforms in the past decade has altered the character of communication practices also among activists in the WSF? To some extent, yes: recent fieldwork conducted at the WSF 2018 in Salvador, Brazil, revealed that in the absence of sustained organising and adequate resources and infrastructure to support collaborative alternative media production, the ready availability of corporate social media platforms offers an easy option. There is also a generational divide between young 'digital natives' and an older generation of community- and alternative media activists who value participatory communication using activistcontrolled technologies. Corporate social media, however, is by no means the only game in town. Though creating collective communication spaces free from corporate control is by no means easy in the current context, it remains a strong ambition among media activists in the WSF, many of whom see themselves as part of a movement focused on media democratisation and communication rights. Media activists in the WSF have worked to put media and technology issues on the global civil society agenda by organising seminars and workshops at social forums, and, since 2009, the World Forum of Free Media (FMML, for the Portuguese Fórum Mundial de Mídia Livre) has been held alongside many editions of the WSF. Defined by its Charter of Principles as a "movement for freedom of expression and the fight for another form of communication" (World Forum of Free Media 2015: np), the FMML brings together media activists working in diverse contexts and at multiple scales - ranging from community radio activists to national media reform advocacy groups and international NGOs working on global issues such as internet governance. Though diverse, the actors that gather at the FMML share a concern to democratise media and empower grassroots communities to communicate on their own terms. This form of media activism, which is centrally concerned with the democratisation of media and communication (see Hackett \& Carroll 2006; Stein, Kidd \& Rodríguez 2009; Milan 2013), offers hope that current processes of commodification and individualisation are not inevitable or irreversible. It seems essential to the realisation of the kind of decentred, distributed and multi-scalar global public sphere proposed here. 


\section{Conclusion}

This article has explored activist communication practices in the WSF to develop an understanding of the 'global public sphere' as decentred, distributed and made up of potentially overlapping and interlinked publics at multiple scales. It has emphasised the importance of affective investment in the idea of global connectedness, and shown how activists engage in the creation of publics that are place-based yet global in outlook. The article has demonstrated the utility of a practice approach to media research, showing how this enables an understanding of publics as constituted through communication practices (not just through the circulation of discourse) and brings into view a range of practices beyond - or 'below' - the self-evidently global. It has questioned the uncritical use of categories such as 'global' and 'local' by arguing that these may function to reproduce hierarchies between cosmopolitan elites and subaltern place-based actors, and showed how activist communication practices in the WSF complicate both conventional hierarchical understandings of scale and contemporary theorisations of publics as distributed networks comprised of individual nodes. The public-making practices discussed here underline the continued importance of collective communication spaces in which subordinate groups can develop their own discourses, knowledges and identities. This means a range of different publics at multiple scales (depending on the actors and issues involved) are needed. The realisation of such publics, and connections between them, depends at least in part on the democratisation of media and communication; specifically, the strengthening of community- and public sector media vis-à-vis the corporate giants that currently dominate the media landscape.

\section{Declaration of Conflicting Interests}

The Author declares that there is no conflict of interest.

\section{Funding}

The findings presented here are drawn from a larger project about media activism in the World Social Forum, partly funded by an ESRC doctoral studentship (ES/F022557/1).

\section{References}

Atton, C. (2002) Alternative media. London: SAGE Publications.

Barassi, V. (2015a) 'Social media, immediacy and the time for democracy: critical reflections on social media as "temporalizing practices", in L. Dencik and O. Leistert (eds) Critical perspectives on social media and protest: between control and emancipation. London: Rowman \& Littlefield, pp. 73-88.

Barassi, V. (2015b) Activism on the web: everyday struggles against digital capitalism. London: Routledge 
Bennett, W.L. and Segerberg, A. (2013) The logic of connective action: digital media and the personalization of contentious politics. Cambridge: Cambridge University Press.

boyd, d. (2011) 'Social network sites as networked publics: affordances, dynamics and implications', in Z. Papacharissi (Ed.) Networked self: identity, community, and culture on social network sites, pp. 39-58. London: Routledge.

Butler, J. (1990) Gender Trouble. London: Routledge

Conway, J. (2008) 'Geographies of transnational feminisms: the politics of place and scale in the world march of women', Social Politics: International Studies in Gender, State and Society, 15 (2): 207-231.

Conway, J. (2012) Edges of global justice: the World Social Forum and its 'others'. London: Routledge.

Couldry, N. (2004) 'Theorising media as practice', Social Semiotics, 14 (2): 115-132.

Couldry, N. (2012) Media, society, world: social theory and digital media practice. Cambridge: Polity Press.

Downing, J.D.H. (2001) Radical media: rebellious communication and social movements. London: Sage.

Fotopoulou, A. (2017) Feminist activism and digital networks: between empowerment and vulnerability. London: Palgrave Macmillan.

Fraser, N. (1990) 'Rethinking the public sphere: a contribution to the critique of actually existing democracy', Social Text 25/26: 56-80.

Fraser, N. (2007) 'Transnationalizing the public sphere - on the legitimacy and efficacy of public opinion in a post-Westphalian world', Theory Culture \& Society, 24 (4): 7-30

Hackett, R.A. and Carroll, W.K. (2006) Remaking media: the struggle to democratize public communication. London: Routledge.

Jackson, S. (2011) Social works: performing art, supporting publics. London: Routledge

Juris, J.S. (2008) Networking futures: the movements against corporate globalization. Durham: Duke University Press.

Juris, J.S. (2012) 'Reflections on \#Occupy Everywhere: Social media, public space, and emerging logics of aggregation', American Ethnologist, 39 (2): 259-279.

Kaun, A. (2015) "'This space belongs to us!": protest spaces in times of accelerating capitalism', in L. Dencik and O. Leistert (eds) Critical perspectives on social media and protest: between control and emancipation, pp. 89-108. London: Rowman \& Littlefield,

Kelty, C.M. (2008) Two bits: the cultural significance of free software. Durham: Duke University Press.

Leistert, Oliver (2015) 'The revolution will not be liked: on the systemic constraints of corporate social media platforms for protest', in L. Dencik and O. Leistert (eds) Critical perspectives on social media and protest: between control and emancipation, pp. 35-52. London: Rowman \& Littlefield.

Lünenborg, M. and Raetzsch, C. (2017) 'From Public Sphere to Performative Publics: Developing Media Practice as an Analytic Model', in Foellmer, S., 
Lünenborg, M., and Raetzsch, C. (eds) Media Practices, Social Movements, and Performativity: Transdisciplinary Approaches. London: Routledge, pp. 13-35.

Marres, N. (2016) Material participation: technology, the environment and everyday publics. London: Palgrave Macmillan.

Mattoni, A. (2016) Media practices and protest politics: how precarious workers mobilise. London: Routledge

Mattoni, A. and Treré, E. (2014) 'Media practices, mediation processes, and mediatization in the study of social movements', Communication Theory, 24 (3): 252-271.

Milan, S. (2015a) 'From social movements to cloud protesting: the evolution of collective identity', Information, Communication \& Society, 18 (8): 887-900.

Milan, S. (2015b) 'When algorithms shape collective action: social media and the dynamics of cloud protesting', Social Media + Society, 1 (2).

Milan, S. (2013) Social movements and their technologies: wiring social change. London: Palgrave Macmillan.

Osterweil, M. (2004) 'A cultural-political approach to reinventing the political', International Social Science Journal, 56(182): 495-506.

Papacharissi, Z. (2010) A private sphere: democracy in a digital age. Cambridge, UK: Polity.

Pleyers, G. (2008) 'The World Social Forum, a globalisation from below?' Societies Without Borders, 3 (1): 71-89.

Poell, T., and van Dijck, J. (2016). 'Constructing public space: global perspectives on social media and popular contestation', International Journal of Communication, 10: $226-234$.

Reckwitz, A. (2002) 'Toward a theory of social practices: A development in culturalist theorizing', European journal of social theory, 5(2), pp. 243-263.

Rodríguez, C. (2001) Fissures in the mediascape: an international study of citizens' media. Cresskill, NJ: Hampton Press.

Sassen, S. (2006) Territory, authority, rights: from medieval to global assemblages. Princeton: Princeton University Press.

Schatzki, T. R. (2001) 'Introduction: practice theory', in Schatzki, T. R., Knorr Cetina, K., and von Savigny, E. (eds) The Practice Turn in Contemporary Theory. London: Routledge, pp. 1-14.

Schatzki, T. R., Knorr-Cetina, K. and von Savigny, E. (2001) The Practice Turn in Contemporary Theory. London: Routledge.

Shove, E., Pantzar, M. and Watson, M. (2012) The Dynamics of Social Practice: Everyday Life and how it Changes. London: SAGE Publications.

Smith, J. (2004) 'The World Social Forum and the challenges of global democracy', Global Networks, 4(4), pp. 413-421.

Stein, L., Kidd, D. and Rodríguez, C. (2009) Making our media: global initiatives toward a democratic public sphere. Vol. 2. Cresskill, NJ: Hampton Press.

Stephansen, H.C. (2013a) 'Starting from the Amazon: communication, knowledge and politics of place in the World Social Forum', Interface: a journal for and about social movements, 5 (1), 102-127. 
Stephansen, H.C. (2013a) 'Connecting the peripheries: networks, place and scale in the World Social Forum process', Journal of Postcolonial Writing, 49(5), 506518.

Stephansen, H.C. (2016) 'Understanding citizen media as practice: agents, processes, publics', in M. Baker and B. Blaagaard (eds) Citizen media and public spaces: diverse expressions of citizenship and dissent, pp. 25-41. London: Routledge.

Stephansen, H.C. (2017) 'Media Activism as Movement? Collective Identity Formation in the World Forum of Free Media', Media and Communication, 5 (3), 59-66.

Treré, E. (2012) 'Social Movements as Information Ecologies: Exploring the Coevolution of Multiple Internet Technologies for Activism', International Journal of Communication, 6, pp. 2359-2377.

Varnelis, K. (ed.) (2008) Networked Publics. MIT Press.

Volkmer, I. (2014) The global public sphere: public communication in the age of reflective interdependence. Cambridge: Polity Press.

Warner, M. (2002) Publics and counterpublics. New York: Zone Books.

World Forum of Free Media (2015) World Charter of Free Media. World Forum of Free Media. Available from http://www.fmml.net/spip.php?article146 [Accessed 10 April 2017].

Ylä-Anttila, T. (2005) 'The World Social Forum and the globalization of social movements and public spheres', ephemera: theory, politics and organization, 5 (2): 423-442. 